А.І. Міночкін, О.Я. Сова, О.О. Марилів, О.О. Троцько. Збірник наукових пращъ BITI. Вип. № 1. 2017. С. 61-70.

7. Павлов А.А. Исследование влияния различных параметров на характеристики передачи данных беспроводных многошаговых сетей / А.А. Павлов, И.О. Датьев Труды Кольского научного иентра. Информационные технологии. 6/2016(40). Вып. 7. 2016. C. 45-55. URL: https://www.iimm.ru/publikatsii/sbornik-nauchnyhtrudov-2016/ (дата звернення 09.03.2021).

DOI https://doi.org/10.30525/978-9934-26-046-9-10

\title{
ВИГОТОВЛЕННЯ ДЛЯ НАВЧАЛЬНОГО ПРОЦЕСУ 3D МОДЕЛІ ЗРІЗУ ПРИМІЩЕННЯ З БЕЗПРИВ'ЯЗНИМ БОКСОВИМ УТРИМАННЯМ КОРІВ
}

\author{
Нагорний С. А. \\ кандидат сільськогосподарських наук, \\ доцент кафедри технічних систем і технологій тваринництва \\ Харківський національний технічний університет сільського \\ господарства імені Петра Василенка \\ м. Харків, Україна \\ Чалая О. С. \\ кандидат сільськогосподарських наук, \\ дочент кафедри агротехнологій та екології \\ Харківський національний технічний університет сільського \\ господарства імені Петра Василенка \\ м. Харків, Украӥна \\ Криворучко Ю. І. \\ кандидат сільськогосподарських наук, \\ дочент кафедри технології тваринництва та птахівництва \\ Харківська державна зооветеринарна академія \\ м. Харків, Україна
}

Стрімкий розвиток інформаційних технологій $є$ характерною складовою сучасності, яка призводить до значної перебудови інформаційного середовища сучасного суспільства, відкриваючи нові можливості 44 
його прогресу, що знаходить своє відображення, перш за все, в сфері освіти [1, с. 95].

Для вивчення питань сучасних технологій виробництва молока було розроблено i виготовлено фрагмент зрізу приміщення для безприв'язного боксового утримання корів у масштабі 1:36 (рис. 1), з повною візуалізацією внутрішнього (колони, огорожа кормового столу, комплекти боксового обладнання для відпочинку тварин, гноє - та кормогноєві канали, скрепери для видалення гною, групові автонапувалки тощо) та зовнішнього (опорна решітка та зовнішній утримувач бокових штор, світлоаераційний коньок) технологічного устаткування.

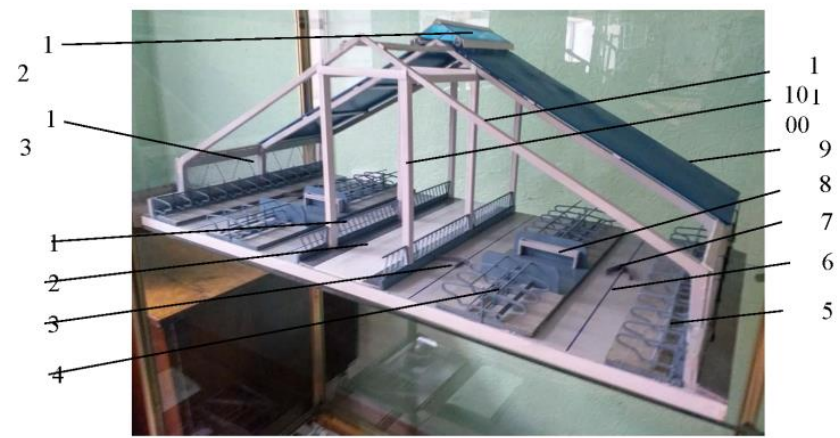

Рис. 1. Загальний вигляд зрізу приміщення для безприв'язного боксового утримання корів

1 - огорожа кормового стола; 2 -кормовий стіл; 3 - кормогноєвий канал; 4 - комплект здвоєних боксів для відпочинку тварин; 5 - комплект пристінних (одинарних) боксів для відпочинку тварин; 6 - гноєвий канал; 7 - скреперна установка для видалення гною; 8 - групова автонапувалка; 9 - крівля; 10 - колони; 11 - напіврами; 12 - світлоаераційний коньок ; 13 - опорна решітка та зовнішній утримувач бокових штор.

Графічне виконання основних технологічних елементів виконувалося у програмі КОМПАС 3D після чого на 3D принтері Malyan M180 окремо роздруковувалися найбільш складні деталі комплекту боксів (здвоєні та одинарні бугеля, верхні та бокові обмежувачі, грудний упір, платформи під бокси та решітки кормового стола) (рис. 2), не з'єднуючи їх між собою, оскільки можливості даного принтера у цьому напрямку обмежені і друк відбувається лише в одній площині, послідовно нарощуючи шари матеріалу за допомогою екструдера, який під високою температурою розплавляє пластикову нитку. В по- 
дальшому всі елементи з'єднувалися між собою вручну за допомогою суперклея.

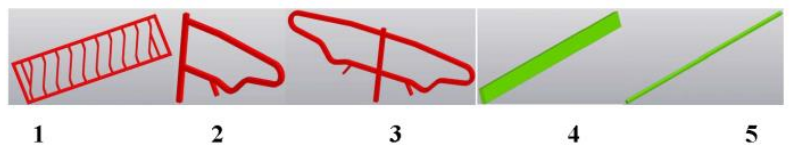

Рис. 2. Елементи моделі, роздруковані на 3D принтері

1 - огорожа кормового стола; 2 - пристінний одинарний бугель; 3 - міжрядний здвоєний бугель; 4 - грудний упір; 5 - верхні та бокові обмежувачі.

Усі інші конструктивні елементи моделі (напіврами, колони, огороджуючі конструкції) виготовлялися із ПВХ панелей, товщиною 2 мм., а також підручних пластикових будівельних матеріалів (вуголки, коробки закріплення дротів тощо) вирізалися, зклеювалися, відповідно до масштабу вручну, після чого фарбувалися під реалістичні кольори матеріалів, що використовуються безпосередньо в справжніх корівниках.

Використання 3D моделі зрізу приміщення для безприв'язного боксового утримання корів, при вивченні сучасних технологій виробництва молока, довело його перевагу і доцільність його використання у порівнянні з його відображенням в 2D форматі [2, с. 84; 3, с. 174]. Також візуалізована демонстрація зразка приміщення дозволяє більш широко охопити вивчення будови і принципів роботи усіх технологічних елементів у сучасному промисловому скотарстві, а саме:

- розрізняти варіанти боксового та комбібоксового технологій безприв'язного утримання корів;

- порівнювати раціональність використання корисної робочої площі приміщень;

- аналізувати використання різних конструкцій огорож кормового столу (діагональні решітки, самофіксуючі типу «Хедлок» та просто у вигляді надхолкового обмежувача), а також обгрунтувати параметри фронту годівлі та напування за різних систем і способах утримання;

- рекомендувати можливість використання тієї чи іншої скреперної установки для видалення гною, залежно від прийнятої технології утримання (з використанням підстилки у зоні відпочинку чи гумових матів для комфорту тварин);

- розрахувати освітленість природну та необхідну штучну у різних зонах розміщення тварин; 
- обгрунтувати роботу системи вентиляції, залежно від періоду року;

- досліджувати відповідність різних технологічних елементів (висоту, ширину та глибину боксів, залежно від живої маси тварин і їх кількість в одному ряду, ширину гноє- та гноєкормового каналів тощо) до норм технологічного пректування з урахуванням комфорту тварин;

- визначати особливості монтажу окремих технологічних елементів.

\section{Література:}

1. Вакулюк В.М., Семенова Н.Г. Использование мультимедиа технологий в лекционном курсе . Современные наукоемкие технологии. 2004. Вип. 2. С. 95-97.

2. Кульбаба С.В., Нагорный С.А., Чигрин А.А./Мультимедиа технологии графики в образовательном процессе. Вісник ХНТУСГ ім. Петра Василенка «Технічні системи і технології тваринниитва». 2014. Вип. 144. Харків. С. 83-88.

3. Нагорний С. А., Чалая О. С., Чалий О. І. Розробка і використання $3 \mathrm{~d}$ моделей у навчальному процесі. Актуальні питання технологій тваринниџтва та ветекринарної медицини. 2020. Харків: РВВ ХДЗВА. С. 172-176. 